\title{
El ritmo como expresión de lo erótico en la poesía de Gonzalo Rojas
}

\author{
Mauricio 0 stria G onzález
}

Universidad de Concepción

\begin{abstract}
Resumen
La escritura poética, por ser precisamente escritura, no contiene en su materialidad los sonidos, entonaciones o ritmos concretos, propios de toda secuencia oral real, sino sólo las imágenes acústicas correspondientes a las unidades distintivas. Sin embargo, conserva fuertemente sus vínculos con lo oral (como un pentagrama). Entonces, la persistencia de lo fónico en la poesía la preserva como fenómeno que, no obstante su soporte escritural, conserva su virtualidad sonora, de modo que el lector de poesía "oye mentalmente, detrás del trazo las palabras del texto, su música verbal" ( 0 ctavio Paz). Esto es lo que sucede cabalmente con el discurso lírico de Gonzalo Rojas, quien no solamente prefiereen prólogos y presentaciones la lectura en voz alta, sino que en sus poemas recurre a menudo a sugestiones de oralidad que incluyen todo tipo de procedimientos que la proyecten a la página. Esto es especial mente evidente en la expresión de los ritmos del amor.
\end{abstract}

Palabras claves: Poesía chilena, ritmo, erotismo, oralidad.

\section{Abst Ract}

Poetic writing, just because of its condition of writing, does not contain in its physical substance the concrete sounds, intonations, or rithms which characterize any actually spoken sequence, but it contains only the acoustic images that correspond to distinctive sound units. Nevertheless, it firmly conserves its links to orality (like a musical staff); therefore, the persistence of sonority in poetry preserves it as a phenomenon that, in spite its scriptural support, maintains its sonorous virtuality, so that a poetry reader "listens in his mind, behind the written words, their oral music" (O ctavio Paz). This is what fully happens with G onzalo Rojas' lyrical discourse. The poet not only prefers to read aloud his prologues and presentations, but also in his poems often resorts to suggestions of orality, which include all types of procedures that project it on the written page. This is especially evident in love rithms.

KEYWORDs: Chilean poetry, rithm, eroticism, orality.

Recibido: 12.05.2003. Aceptado: 26.05.2003. 
Y

DICE EL poeta: "Todo crece con el ritmo" (595)1; porque uno nace y "desnace al mismo tiempo" (596). Por eso, su poesía ofrece en una misma trama lo numinoso y lo cotidiano, lo tanático y lo erótico, lo riguroso y lo placentero, lo físico y lo metafísico, es decir el juego dela vida trasmutada en sonido con sentido, en cadencia rítmica. Sístole y diástole, inspiración y expiración, hartazgo y deseo - o como dice el poeta, "hartazgo y orgasmo" 0 también "alternancia del esperma y de la respiración" (232)- . Poesía en movimiento, palabras que se encuentran, chocan, copulan, se distancian, dicen lo uno y lo otro, el yo y el tú, el esto y el aquello, el yin y el yang. Poesía y encuentro, poesía y eros vienen a ser lo mismo en la ambigüedad sonora o en la incierta página en blanco: "Falo el pensar y vulva la palabra" (Paz, 245):

\section{H artazgo y orgasmo son dos pétalos en español de un mismo lirio tronchado cuando piel y vértebras, olfato y frenesí tristemente tiritan en su blancura última, dos pétalos de nieve y lava, dos espléndidos cuerpos deseosos y cautelosos, asustados por el asombro, ligeramente heridos en la luz sanguinaria de los desnudos:} un volcán

que empieza lentamente a hundirse,

Así el amor en el flujo espontáneo de unas venas Encendidas por el hambre de no morir, así la muerte: La eternidad así del beso, el instante Concupiscente, la puerta de los locos. Así el así de todo después del paraíso:

ábrenos de una vez.

$$
\text { - Dios, }
$$

("Pareja humana", 220)

El sentido brota de la cadencia rítmica que es sonido y significado, frase e imagen simultánea e inseparablemente. "El lenguaje - con mayor razón la poesía-, igual que el universo, es un mundo de llamadas y respuestas; flujo y reflujo, unión y separación, inspiración y respiración. Unas palabras se atraen, otras se repelen y todas se corresponden: 'metamorfosis de lo mismo'. El habla es un conjunto de seres vivos, movidos por ritmos semejantes a los que rigen a los astros y a las plantas" (Paz, El arco..., 31). Secuencias y pausas, palabras y silencios, el ritmo es un acorde 0 una analogía, una reiteración o una ruptura, una armonía o un contraste. El lenguaje "es un continuo vaivén de frases y asociaciones verbales regido por ritmo secreto" (Paz, El arco..., 52); afinidades y repul-

${ }^{1}$ Citamos por G onzalo Rojas (2000). 
siones se suceden atraídas por fuerzas idiomáticas inmanentes. La poesía no hace más que convocar ese ritmo por medio de metros, rimas, aliteraciones, paronomasias, encabalgamientos, anáforas, retruécanos, paralelismos, correlaciones y otros procedimientos.

Anoche te he tocado y te he sentido

Sin que mi mano huyera más allá de mi mano,

Sin que mi cuerpo huyera, ni mi oído:

De un modo casi humano

Te he sentido.

Palpitante,

$\mathrm{N}$ o sé si como sangre o como nube

Errante,

Por mi casa, en puntillas, oscuridad que sube,

O scuridad que baja, corriste centelleante.

Corriste por mi casa de madera

Sus ventanas abriste

Y te sentí latir la noche entera,

$\mathrm{H}$ ija de los abismos, silenciosa,

Guerrera, tan terrible, tan hermosa

Q ue todo cuanto existe,

Para mí, sin tu llama, no existiera

("O scuridad hermosa", 144).

Ya en el ir y venir de los títulos de los poemas se encabalgan el amor y el olvido, la aventura y el éxtasis, el rencor, el despecho, la nostal gia, el convite y la búsqueda, la evocación que convoca y dispersa sen saciones eimágenes: "L atín y jazz", "Alcohol y sílabas", "El sol y la muerte", "El principio y el fin", "Rotación y traslación", "U Itimamente tú que yéndote te vas", "¿Q ué se ama cuando se ama?", "Q uedeshím Q uedeshóth", "Asma es amor", "Culebra o mordedura", "Eso que no se cura sino con la presencia y la figura", "Tacto y error", "O rquídea en el gentío", "Extasis del zapato", "Lectura de la rosa"... Al fin que "El Ritmo ha de ser océano profundo / que al hombre y la mujer amarra y desamarra / nadie sabe por qué" ("C arta para volvernos a ver", 307).

"Al principio, la poesía fue oral: una columna que asciende y que está hecha de versos, es decir, de unidades verbales rítmicas, que aparecen y desaparecen, una tras otra, en un espacio invisible hecho de aire (...) La poesía se apoyó, más tarde, en la escritura; desde entonces se ha servido del signo escrito y de la palabra hablada" (Paz, La otra voz, 121). La poesía de Gonzalo Rojas ha permanecido fiel a esas fuentes primeras, ese origen oral: "no estoy por la partitura efímera (...) sino por la oralidad y por la sintaxis del callamiento. De ahí que, cuando escribo mis líneas menesterosas de aprendiz interminable, lo primero 
que hago es ponerme en piey leerlas en voz alta. No al lector, al oyente" (M etamorfosis, 588).

Te juré no escribirte. Por eso estoy llamándote en el aire Para decirte nada, como dice el vacío: nada, nada, sino lo mismo y siempre lo mismo de lo mismo que nunca me oyes, eso que no me entiendes nunca, aunque las venas te arden de eso que estoy diciendo.

y te quedas inmóvil, oyendo que te llamo en el abismo.

("Retrato de mujer", 221).

En todas las formas escritas de la poesía, el signo gráfico está siempre en función del oral. El lector advertido oye siempre, detrás del trazo, las palabras del texto, su música verbal (Paz, La otra voz, 122). D eahí que Gonzalo Rojas no sólo evoque en prólogos y presentaciones la lectura en voz alta, sino que sus poemas recurren a menudo a sugestiones de oralidad que incluyen repeticiones, tartamudeos, avances y retrocesos, correcciones, anacolutos, fugas, muletillas, explicaciones, coloquialismos, juegos de palabras, colisiones entre el sonido y el significado:

te iba tartamudeante a / decir:(...) esdrújulo, libérrimo del mar (215):

Eléctricas (.... y germinan, germinan...

Cálidas (...) arcángeles (...) que saben lo que saben como sabela tierra... // Tan livianas, tan hondas, tan certeras (...) H embras, hembras...

("Las hermosas", 223)

Pero los meses vuelan como vuelan los días, como vuelan

En un vuelo sin fin las tempestades, / Pues nadie sabe nada de nada

("La loba", 228).

así sople (...) así viva (así padezca (...), así me acueste (...), así toque mi cítara (...), así se abra una puerta

("Carta del suicida", 242)

insaciable de la lascivia, / riera (frenético el frenesí

(“El fornicio", 244)

Si ha de triunfar el fuego sobre la forma fría,

D escifraréa M aría. Hija del fuego,

La elegancia del fuego, el ánimo del fuego,

El esplendor, el éxtasis del fuego.

("Rapto con precipicio", 249) 
... y estás ahí mirándome, (...) y estás ahí mirándome, (...)// Y no hay sábana donde dormir, y no hay, y no hay / sol en ninguna parte, y no hay estrella al guna

("El amor", 252).

Podría estar citando textos todo el día. En el poema "O riana” se juega significativamente con el origen etimológico del nombre ( 0 riana: de 0 , oris =boca, de donde oral y oralidad) de modo de sugerir la identidad entre palabra (oral)/poesía y mujer. El texto termina con una serie de rimas lúdicas con ecos huidobrianos.

El poema "D el sentido" también funciona como arte poética. Se trata de un breve eintenso texto donde la metonimia se metaforiza hasta condensarse en un solo sonido vocal, suma y cifra del sentido-universo-mujer-eros:

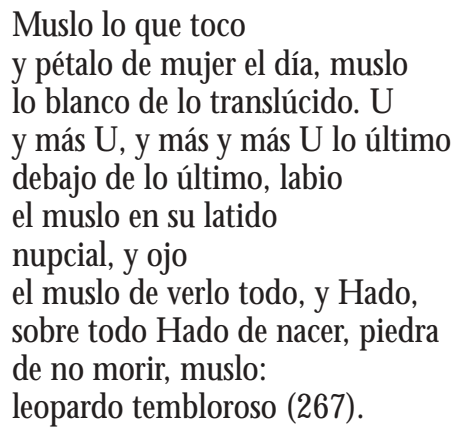

El sistema de correspondencias que vincula palabra-oralidad-poesía-mujereros encarna continuamente en metáforas cuyo término explícito es un instrumento musical que en su forma recuerda, del algún modo, la figura femenina, como la cítara o el arpa. (Véase poemas como "Cítara mía" o "Vocales para H ilda"). Y es quizá - entre varios- el poema "La palabra placer" uno de los más claros poemas metapoéticos, es decir, uno de aquellos en que mejor se define el sentido del conjunto textual y en el que la palabra y la mujer objeto del deseo se unimisman hasta confundirse: "La palabra placer, como corría larga y libre por tu cuerpo la palabra placer (...) cómo lo músico vino a ser marmóreo..." (273).

Por fin, el poema "D as heilige" ("Lo santo", lo numinoso) parece reunir todos los sentidos del libro en una visión en que sonidos lingüísticos, música y órganos genitales femeninos se funden en un arder vertiginoso humano y cósmico, frenesí dionisiaco, que asume carácter sagrado: Es la apoteosis de la pasión monopólica del poemario:

Raro arder aquí todavía. ¿Vagina o clítoris? Clítoris por lo esdrújulo de la vibración, entrelaípsilon 


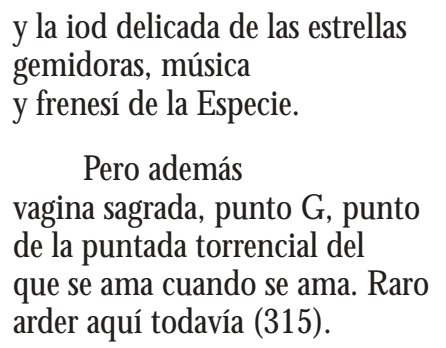

Terminemos citando la declaración 'epicéntrica', 'axiomática' del autor: "el amor es, acaso, la única utopía que nos queda".

\section{REFERENCIAS}

Paz, 0 ctavio. 1955. El arco y la lira, Fondo de Cultura Económica, M éxico.

------- 1990. La otra voz, Seix Barral, Barcelona.

Rojas, Gonzal o. 2000. M etamorfosis de lo mi mo, Visor, M adrid. 